\title{
Comment
}

\section{PATENT RIGHTS IN DEPARTMENT OF DEFENSE RESEARCH AND DEVELOPMENT CONTRACTS}

In the current fiscal year the Department of Defense estimates expenditures of over $\$ 3,000,000,000$ in research and development $t^{1}$-more than all the armed services together spent during World War $\Pi .^{2}$ By the end of $1957,50,000$ companies were active in the missile field alone as contractors and subcontractors for the Department of Defense. ${ }^{3}$ Because of this immense amount of money and effort, the disposition of patent rights in imventions arising under Defense Department research and development contracts is of great public importance. ${ }^{4}$ These rights are regulated by a patent rights clause in the contract which grants a license to the Government and defines other rights of the parties. ${ }^{5}$

The present clause developed from the experience of World War I when the services made no provision for patent rights in research and development contracts, ${ }^{6}$ and as a result found themselves "paying for the use of inventions [they] had financed or even suggested."7 During the 1920's efforts to remedy the situation were mainly limited to litigation, ${ }^{8}$ and the decade's end found the problem still unresolved..$^{9}$ However, even without an express contractual stipulation, the Government obtained at least a royalty-free license ${ }^{10}$ and it has been argued that the Government is entitled to full assignment of title in the inventions.11 But wide-

1 Bureau of the Budget, The Budget of the United States Government for the Fiscal Year Ending June 30, 1960, H.R. Doc. No. 15, 86th Cong., 1st Sess., pt. 1 at 445 (1959).

2 The Navy Department spent about $\$ 300,000,000$ on research through contractors. 2 U.S. Dep't of Justice, Investigation of Government Patent Practices and Policies Report and Recomindendations of the Attorney General to the President 291 (1947) [hereinafter cited as "ATT' $Y$ GEN. REP."]. The War Department had research and development contracts of $\$ 525,000,000.2$ ATT'Y GEN. REP., op. cit. supra at 409.

3 Time, Dec. 30, 1957, p. 55.

4 The subject is currently being studied by the Patents, Tradsmarks, and Copyrights Subcommittee of the Senate Judiciary Committee. See S. REP. No. 1430, 85th Cong., 2d Sess. 6-8 (1958).

532 C.F.R. \$ 9.107-1 (Supp. 1959). Each of the services uses the same clause, but have added minor regulations of their own which are not discussed in this Comment.

62 Atr'y Gen. Rep. 292, 455.

7 See id. at 292.

8 In Ordnance Eng'r Corp. v. United States, 68 Ct. Cl. 301 (1929), supplemented, $73 \mathrm{Ct} . \mathrm{Cl}$. 379 (1931), cert. denied, 302 U.S. 708 (1937), the Navy successfully argued that one of its contractors could not sue the Government for infringement of patents resulting from its development contracts. This decision is contrary to two prior rulings of the Attorney General, 32 OPS. ATT'y GEN. 556 and 563 (1921), although it has been suggested both are explamable on special circumstances involved, 3 ATI'Y GEN. REP., op. cit. supra note 2 at 160 n.190. Some importance is attached to these decisions, however, since they seem to be the only reports on the subject: even the $\mathrm{CCH}$ Government Contracts Reporter contains no cases on the patent clause. Two reasons for lack of litigation on this subject may be that the rights given contractors by the clause satisfy them and that contractors hesitate for public relations reasons to contest the Government's rights.

${ }^{2}$ See discussion of the variety of patent clauses used in contracts of the different services in text to note 13 infra.

10 Ordnance Eng'r Corp. v. United States, $68 \mathrm{Ct}$. Cl. 301 (1929), supplemented, $73 \mathrm{Ct} . \mathrm{Cl}$. 379 (1931), cert. denied, 302 U.S. 708 (1937).

113 Atr'y Gen. Rep. 159; 1 Atr'y Gen. Rep. 78; Kreeger, The Control of Patent Rights Resulting from Federal Research, 12 LAW \& CONTEMP. PROB. 714, 734 (1947). 
spread use of the present patent clause reserving merely a government license $\mathrm{e}^{12}$ renders the discussion academic.

During the 1930's some components of the armed services used contract clauses which settled patent-rights questions by in effect reserving "a free government license under patents resulting from the contract and under prior patents of the contractor used in performing the contract."13 As might be expected, the aeronautical arms of the Army and Navy jointly adopted uniform clauses of five different types, ${ }^{14}$ ranging from licenses analogous to shop rights to vesting of title in the Government.

Government patent practice first achieved agency-vide standardization in 1940 in the atomic energy field. ${ }^{15}$ The following year, the Navy Department adopted a standard clause ${ }^{16}$ but the War Department waited until April, 1945; ${ }^{17}$ later that year the Navy abandoned its own clause and directed use of the War Department's. For the first time there was a uniform patent clause used throughout the armed services, ${ }^{18}$ which, since unification of the services, ${ }^{10}$ is authorized by the Armed Services Procurement Act of $1947 .^{20}$ This clause, substantially unchanged until 1956 , is essentially designed to give the contractor first chance to get both domestic and foreign patents to inventions resulting from the contract. The Government acquires a royalty-free license, and may obtain foreign or domestic title if the con-

12 The present clause grants the Government a nonexclusive, irrevocable, nontransferable, royalty-free license. 32 C.F.R. $\$ 9.107-2$ (b) (Supp. 1959). This is in many respects analogous to the employer's shop right to use an employee's imvention in bis business. See United States v. Dubilier Condenser Corp., 289 U.S. 178 (1933); 3 ATT'Y GEN. REP. 140.

132 ATr'y GEN. REP. 294. The Navy Bureau of Ordnance in 1930, and the Bureau of Aeronautics in 1932, adopted this type of clause. Id. at 295. The Army Air Corps had a standard clause in 1936 [id. at 458] but the remaining services apparently gave little attention to the problem.

14 Id. at 297. Apparently optional, the clauses were to be used in aircraft engine and aeronautical accessories contracts.

15 Hearings on S.1717 Before the Senate Special Committee on Atomic Energy, 79th Cong., $2 d$ Sess., pt. 3 at 332 (1946). Power to determine disposition of title arose under a contract clause known as the "short form," and was used where the Government took the initiative in grouping scientists and technicians to perform work where information was not available from a single organization. However, where the contractor had an established position in the field, or possessed a fund of information the Government wanted to exploit, a "long form" was used to give the Government a hicense while the contractor retained title. But by the spring of 1943, the Government acquired title to patents on inventions made on the project. Ibid. In addition to research and development, contracts for quantity production of equipment ranged from sewers to apparatus in the heart of the atomic bomb. Id. at 338. Consequently, four variations of the short form contract clause came into use, under which the Government decided what rights were to be retained. The form used depended on type of iten contracted for, desirability of patenting, and closeness the contract bore to the project.

For a discussion of current patent practices in atomic energy fields, see Riesenfeld, Patent Protection and Atomic Energy Legislation, 46 CaLrF. L. Rsv. 40 (1958).

162 ATT'Y GEN. REP. 299.

172 ATT'Y GEN. REP. 459. While the Army had considered adoption of standard clauses in 1920 and 1921, no action was taken. Id. at 457. The Army Quartermaster Corps adopted the unique practice of seeking title rather than a license for a short period during World War II. See note 166 infra.

182 ATT'Y GEN. REP. 303.

1961 Stat. 499 (1947), as amended, 5 U.S.C. $\$ \S 171-72$ (1958).

20 Ch. 65, 62 Stat. 21 (1948). Specific authority is now found in 10 U.S.C. $\$ 2202$ (1959), which derives from 66 Stat. 537 (1952), which, in 1952, amended the Armed Forces Procurement Act. The act, itself, was repealed in 1956, 70A Stat. 120, and was reenacted into positive law as 10 U.S.C. $\$ \S 2202,2301-14,2381,2383$ (1959). 
tractor does not desire ownership. In that case, a license results to the contractor. The various provisions of the clause will be analyzed in this Comment to show the nature and extent of these patent rights.

\section{THE CLAUSE}

Basically, the present clause is to be included in any Department of Defense contract which has research and development as one of its purposes, ${ }^{21}$ but whether the purpose is to be main, substantial, or merely incidental is not clear. While it has been suggested that merely incidental purposes are beyond the scope of the clause, ${ }^{22}$ examination of an escape provision indicates that many incidental research and development purposes are included. Under the escape provision, inventions constructively reduced to practice prior to award of the contract may be excluded from a Government license when the contractor demonstrates that his research and development costs and patenting expenses are large compared with the amount of the contract; ${ }^{23}$ or that the invention is of a basic material which the contract was not intended to develop. ${ }^{24}$ These specific exclusions suggest that other incidental research and development purposes are sufficient grounds to include the clause in the contract. Thus, the sweep of "purposes" is wide.

Even though it has been determined that the clause is to be included in the contract, not all inventions are covered. The clause is himited to "subject inventions"25 defined as "any invention, improvement or discovery (whether or not patentable) conceived or first actually reduced to practice" in two situations. The first, and most obvious, is in "the performance of the experimental, developmental,

2132 C.F.R. $\$ 9.107-2$ (b) (Supp. 1959). For the basic contract there is no minimum amount such as that found in the $\$ 3000$ required before a subcontract will come under the clause. 32 C.F.R. 9.107-2(b). Patent Rights Clause para. (g) (Supp. 1959). [Hereinafter, portions of the clause will be cited by paragraph only.] If procurement of a standard item of supply is the subject of the contract, and the manufacturer does research in connection with it, the Government gets no license in resulting patents, since research was not contemplated in the contract. However, inventions resulting from specific product improvement supply contracts are subject to government hicenses. (See text following note 156 infra.) For the differences between supply and research and devclopment contracts, see Lazure, Why Research and Development Contracts Are Distinctive, 17 FED. B.J. 255 (1957).

To some extent, personal service contracts of the Defense Department contain a patentrights clause. 32 C.F.R. $\$ 9.108$ (Supp. 1959). Modification or omission of the clause is permitted by 32 C.F.R. $\$ 7.503-9$ (Supp. 1959) in short term contracts (under one year), but it does not apply to alien scientists. 32 C.F.R. $\$ 7.502$ (1954). The clause implies that these contractors may be treated as employees in accordance with Exec. Order No. 10096, 15 FED. REg. 389 (1950), regulating patent rights of government employees.

Only the patents rights clause applying to research and development contracts to be performed withm the United States, its Territories, its possessions, or Puerto Rico is analyzed in this Comment. Beyond its scope is the distimct clause for research and development contracts to be performed abroad. See 32 C.F.R. $\$$ 9.107-3 (Supp. 1959).

22 Hodges, Patent Policies and Procedures of the Deparment of the Army, $39 \mathrm{~J}$. PAT. OFr. Soc'x 192, 204 (1957).

23 The costs are limited to amounts which can be allocated to the excluded invention, 32 C.F.R. $\$ 9.107-2$ (a) (1) (Supp. 1959), and apparently relate to "experimental, developmental, or research work"-one of the purposes of the contract requiring inclusion of the clause. See also 32 C.F.R. $\$ 15.204(j)$ (1954) which distinguishes "research, experimentation, and development" from "manufacturing and production engineering," and 32 C.F.R. \$ 3.211-2 (Supp. 1959), which illustrates "experimental, developmental, or research work."

24 For discussion of other grounds for exclusion, see text to note 39 infra.

25 Para. (a) (1). 
or research work called for or required under this contract."20 Thus, even though an invention results from work called for or required under the contract, if not research, developmental, or experimental, it is not a subject invention. ${ }^{27}$

The second situation where an invention becomes a subject invention is "in the performance of any experimental, developmental, or research work relating to the subject matter of this contract which was done upon an understanding in writing that a contract would be awarded." 28 The purpose of including these inventions is probably to cover design competitions where the armed services invite prospective contractors to bid. ${ }^{29}$ When the successful bidder is awarded the contract, inventions conceived and reduced to practice before award of the contract become subject inventions. If a contract is not awarded to a prospective contractor, the Government gains no rights in inventions made while engaged in the competition. The clause probably does not cover a situation where the contractor did work on his own, and then sold the product to the Defense Department, if for no other reason than there would be no understanding in writing. ${ }^{30}$ While all inventions falling within the subject-invention classification are licensed to the Government, ${ }^{31}$ only those which reasonably appear to be patentable are subject to conveyance of title, ${ }^{32}$ reporting, ${ }^{33}$ penalties, ${ }^{34}$ and subcontract ${ }^{35}$ provisions of the clause.

The clause covers any invention first actually reduced to practice during performance of the contract and related to it, even though conceived prior to the

26 Para. (a) (1) (A).

27 The same situation is apparent in the second situation of the limitation paragraph (b) (2) (ii). There, when the invention results from contract work, but not experimental, developmental or research work, the invention would not be excluded by the limitation paragraph. It would be excluded by the definition of "subject invention," but the inconsistency with the rest of the clause is apparent. In any event, justification for excluding these inventions from even a governinent license is difficult to see.

28 Para. (a) (1) (B). The problem discussed in note 27 supra is present in this paragraph also. There was no requirement that the understanding be written in the 1953 clause. 32 C.F.R. \$ 9.107-1 (1954).

29 There is a problem, both of policy and interpretation, in one type of design competitions: airplane designs. The Air Corps Act of 1926 authorizes the Secretary of War either to contract with the winner for "furnishing or constructing" items ernbodicd in the winning design or to purchase them. In either case, any department of the government shall have the right to use the design, but "such winner shall, nevertheless, be at liberty to apply for a patent on any features originated by him, and shall be entitled to enjoy the exclusive rights under such patent as he may obtain as against all other persons except the United States Government or its assignee." 44 Stat. 785 (1926), as amended, 10 U.S.C. $\$ \S 2272,2273$ (1958). See also 2 ATr'y GEN. REP. $463, \mathrm{n.172}$. The policy problem created is that it is some indication of congressional intent that a license, not title, should be taken by the Government. The interpretation problem is whether domestic or foreign title may ever be taken by the Goverument when contracts are awarded to winners of airplane design competitions. On the other hand, the contractor could give up title or foreign rights under the contract, which would seem a proper exercise of his "exclusive rights."

32 C.F.R. \$ 9.202-6 (Supp. 1959), provides that technical data submitted with proposals (in response to a request for a proposal) shall be specified to be delivered under the contract when desired by the Government for non-evaluation purposes.

30 Under the 1953 clause, the Government could have obtained a license in this situation by virtue of the "background patents" clause. This was eliminated in the 1956 clause, as discussed below.

31 Para. (b) (2) (iï).

32 Paras. (d) (ii) -(v). See discussion of assignment of title in text following note 68 infra.

33 Paras. (c), (d) (i). Sec discussion of enforcement in text following note 120 infra.

34 Para. (f). See discussion of enforcement in text following note 138 infra.

35 Para. (g). See discussion of subcontracts in text following note 101 infra. 
contract itself.$^{36}$ Possibly because of criticism ${ }^{37}$ of the excessive scope of the clause, some relief is allowed. Inventions constructively reduced to practice and for which a patent application has been filed before the award of the contract may be excluded upon request of the contractor if the contracting officer ${ }^{38}$ finds that one or more of four "equitable circumstances" exist. 30 These are: (a) the contractor's research and development costs and patenting expenses are large compared with the amount of the contract; (b) "the practicability of such an invention has been established as by engineering design"; ${ }^{40}$ (c) the invention covers a basic material not intended to be developed; and (d) the invention is useful only for military purposes and the contractor has no facilities to furnish the item to the Government in production quantities. ${ }^{41}$ Where the contracting officer decides to grant the exclusion, the invention is listed in a schedule attached to the contract and apparently it is not necessary to identify the equitable circumstance on which the exclusion is based. The contracting officer is thus given wide discretion in the exercise of the exclusionary power.

In addition to inventions histed on the schedule, patentable improvements in manufacturing processes of the contractor, conceived during performance of the contract, are excluded from the Government's license. ${ }^{42}$ These belong solely to the contractor or his employees. However, contrary to earlier practice, ${ }^{43}$ the present clause does apply to process patents.44

Department of Defense research and development contracts concerned with atomic energy are a special field in their own right. ${ }^{45}$ Such contracts carry an additional paragraph in the patent rights clause ${ }^{46}$ requiring subject inventions covered by the Atomic Energy Acts of $1946^{47}$ and $1954^{48}$ to fall under the "sole and conclusive power" of the Atomic Energy Commission "to determine whether and where a patent application shall be filed, and to determine the disposition of the title to and rights under any such application or any patent that may issue thereon." 49 The contractor and its employees are even precluded from claiming pecuniary awards or compensation allowed by either Atomic Energy Act. Thus, the treat-

3632 C.F.R. § 9.107-1 (a) (Supp. 1959).

37 See Hodges, supra note 22 , at 205.

$38 \mathrm{~A}$ contracting officer is defined in 32 C.F.R. $\$ 1.201-5$ (Supp. 1959) as an officer or employee of the Defense Department who has been designated to enter into, administer or make determinations regarding contracts.

3932 C.F.R. \$ 9.107-2 (a) (Supp. 1959). See text at note 23 supra.

4032 C.F.R. $\$ 9.107-2$ (a) (2) (Supp. 1959). Thus, if the required patent application has been filed, the constructive reduction to practice is sufficient for exclusion from the license, whether or not, apparently, it is sufficient for either patentability or priority.

41 There seems to be less justification for this ground than the others, although it unay be rationalized as a break for the small contractor.

42 Information on manufacturing processes may be available to the Government (and through it to other contractors) under the technical data provisions. See text to note 161 infra. 432 ATr'y GEN. ReP., op. cit. supra note 2, at 300 (Navy Department), 465 (War Department).

44 Para. (b) (1) now gives the Government a license to "the use of any method."

45 See Riesenfeld, Patent Protection and Atomic Energy Legislation, 46 CALr. T. REv. 40 (1958).

4632 C.F.R. $\$ 9.107-4$ (a) (Supp. 1959). The contractor may only retain license rights and the Atomic Energy Commission las to concur in a deviation. A recent amendment lists three situations in which the Commission is now granting deviations. 32 C.F.R. $\S 9.107-4$ (b) (Supp. 1959).

4760 Stat. 755 (1946), 42 U.S.C. $\$ \$ 1801-19$ (1952).

4868 Stat. 919 (1954), 42 U.S.C. $\$ \$ 2011-2296$ (Supp. V, 1958).

4032 C.F.R. $\$ 9.107-4$ (a) (Supp. 1959). 
ment of inventions relating to atomic energy is vastly different; not only does title to the invention go to the Government, but the contractor might not even have a license. This has met with widespread approval from almost all sources. ${ }^{50}$

\title{
A. The License
}

Once it has been determmed that inclusion of the clause is appropriate, the contract carries the entire clause. ${ }^{51}$ The main operating section reads:

\begin{abstract}
The Contractor agrees to and does hereby grant to the Government an irrevocable, nonexclusive, nontransferable, and royalty-free license to practice, and cause to be practiced by or for the United States Government, throughout the world, each Subject Invention in the manufacture, use and disposition according to law, of any article or material, and in the use of any method. .52
\end{abstract}

Basically, this provision grants the Government a license to all product and process patents on subject inventions. In contrast to the usual license "to make, use and vend," ${ }^{3}$ however, the license under the clause is for the "manufacture, use and disposition according to law."5t The latter terni suggests the Government may have greater rights than mere vending. However, neither the Government nor another contractor is allowed to compete with the first contractor in "providing services or supplies to the general public." 55 This protection extends to the first contractor's commercial licensees in the licensed field. But since the prohibition refers only to the manufacture and use of any subject invention not involving services or supplies, a sale to the public, if a disposition according to law, apparently is permissible although in competition with the contractor. Furthermore, the section implies that another government contractor may compete with the first contractor in using the invention, although the Government itself may not.

The Government's right to a license is further limited ${ }^{58}$ where: (1) an inven-

${ }^{80}$ Riesenfeld, supra note 45, at 58; Boskey, Some Patent Aspects of Atomic Power Development, 21 Law \& ConTEMrP. Pros. 113 (1956) and sources cited thercin; VAUgran, The UNITED States Patent System 315 (1956).

Similar treatment is accorded patent rights resulting from researcl, development or exploration contracts of the National Aeronautics and Space Administration. Section 305(a) of the National Aeronautics and Space Act of 1958, 72 Stat. 426, 42 U.S.C.A. \$ 2457 (a) (Supp. 1959), provides that inventions resulting from such contracts are the "exclusive property of the Unitcd States" unless the Administrator waives these rights in accordance with Section 305(f). Regulations prescribing contract clauses and instructions pursuant to the act were recently issued. See 24 Fed. Reg. 3574 (1959), amending 14 C.F.R. \$ 1201 (1952). See also Maltby, The National Aeronautics and Space Act of 1958 Patent Provisions, 27 GEO. WAsH. L. REv. 49 (1958), for a discussion of the possible impact of the act on the Patent Rights Clause of the Armed Services Procurement Regulations.

5132 C.F.R. \& 9.107-2(b) (Supp. 1959).

52 Para. (b) (1). Formal documents confirming the Government's license rights are provided for by para. (d) (v).

${ }_{53}$ Crown Co. v. Nye Tool Works, 261 U.S. 24, 36-37 (1923).

54 Some indication of the meaning of "disposition according to law" has been given by the United States Supreme Court in discussing permissible disposition of surplus electrical energy from Wilson Dam: "an appropriate means of disposition according to the nature of the property, ... [and] adopted in the public interest, as distinguished from private or personal ends." Ashwander v. TVA, 297 U.S. 288, 338 (1936). For an indication that the scope of "public interest" is very broad in an analogous context (condemnation of land for urban redevelopment), see Berman v. Parker, 348 U.S. 26 (1954).

55 Para. (b) (1). A recent amendment negates this prohitition in civil defense research and development contracts of the Department of Defense. 32. C.F.R. \$ 9.107-5 (Supp. 1959).

50 By para. (b) (2). 
tion is made by other than technical personnel; ${ }^{57}$ (2) a subject invention is conceived prior to the award of the contract but first actually reduced to practice during the course of any of the research and development work; ${ }^{58}$ or (3) the invention is practiced in foreign countries. In these situations, the contractor's duty to grant a license is excused if to do so obligates him to pay royalties (or other compensation) solely because of this performance..$^{58}$

However, the obligation to pay others rarely if ever arises. Upon government authorization allowing great latitude in the contractor's use of patented inventions, ${ }^{60}$ a suit for a contractor's infringement may only be brought against the Government in the Court of Claims. ${ }^{61}$ Such an authorization is required to be inserted in all strictly research and development contracts, ${ }^{62}$ and may be included in contracts not exclusively for research and development. Thus, where the contract contains this authorization, there is no obhgation of the contractor to pay others, and therefore no limitation of the contractor's license to the Government. Even a possible indemnification ${ }^{63}$ of the Government by the contractor is not an obligation to pay others; rather it is to pay a party to the contract. Furtherfore, no obhgation of the contractor to pay others arises where the doctrine of United States $v$. Dubilier Condenser Corp. ${ }^{64}$ gives the contractor shop rights in inventions of his employees.

Possibly the contractor will have extracted from his employees broader patent rights than mere shop rights, ${ }^{65}$ but in that case the Government gets a license any-

67 "Technical personnel" is defined as "any person employed by or working under contract with the Contractor ... who, by reason of the nature of his duties in connection with the performance of this contract, would reasonably be expected to make inventions." Para. (a) (ii). Technical personnel is a narrower group than the employees froin whom a contractor has a common law shop right. See discussion of United States v. Dubilier Condenser Corp., 289 U.S. 178 (1933), at note 12 supra. However, the employees most likely to develop patentable inventions are covered by the technical personnel definition, and their inventions are licensed to the Government whether the inventions are conceived and perfected on the contractor's time or not. If the contractor has no contract with his techmical personnel covering inventions they conceive and perfect in off duty hours, the employee may collect damages in an infringement suit against the Government. See text to note 61 infra.

58 The 1953 clause bmited the Government's license where a subject invention was "conceived prior to any performance of this contract ... but first actually reduced to practice in the course of any such performance." 32 C.F.R. $\$ 9.107-1$ (b) (1954). An invention conceived before award of the contract, but first actually reduced to practice afterward may, as previously noted, be excluded under 32 C.F.R. \$ 9.107-1(a) (Supp. 1959).

E0 Similar situations also excuse conveyance of title when required by paragraphs (d) (ii) (B) or (d) (iv), or conveyance of foreign rights under paragraph (e).

0032 C.F.R. \& 9.102-2 (Supp. 1959). See Te Selle, Authorization or Consent to Infringe Patents in Production for the Government, 26 Geo. WASH. L. REv. 583 (1958).

61 See 28 U.S.C. $\$ 1498$ (1952) and 32 C.F.R. $\$ 9.102$ (Supp. 1959). For a discussion of these suits, see Mickelman, Patents in Government Contracts, 32 J. PAT. OFF. Soc'y 778, 780-785 (1950). Claims of nationals of the United Kingdom were formerly referred to a special committee in accordance with 32 C.F.R. $\$ 9.110$ (1954). This provision is omitted in the current regulations.

6232 C.F.R. \$ 9.102-2 (Supp. 1959).

6332 C.F.R. \$ 9.103 (Supp. 1959) provides certain contracts shall include a patent indemnity clause and thus the contractor ultimately may bear the damages of an infrimgement suit. 64289 U.S. 178 (1933).

65 "The general practice in industry is to require employees to agree to assign to the employer all inventions relating to the employer's business." 3 ATr'Y GEN. REP. 62.

Judge Thurman Amold, formerly Assistant Attorney General in charge of the Antitrust Division, in testimony before a suhcommittee of the Senate Committee on Military Affairs stated: 
way. Furthermore, the Government's license is not limited to inventions of technical personnel. ${ }^{66}$

While an invention may be excluded from the required grant of a license to the Government, the language of the escape provision ${ }^{67}$ implies that there is no exclusion when conveyance of title or foreign rights is requested, although that causes the contractor to pay royalties to others. Such a result may be an oversight, for the purpose of the escape provision would thereby be thwarted.

\section{B. Assignment of Title}

In all cases, the contractor has "first crack" at patenting an invention. But when the contractor decides not to file a patent application or to discontinue the prosecution of an application already filed, he must so notify the contracting officer. ${ }^{68}$ Upon written request of the contracting officer, the contractor is required to execute the necessary documents to vest title to those subject inventions reasonably appearing patentable in the Government. ${ }^{.9}$ The assignment of title provision,

"Judge Arnold. ... While we did not survey all the industries in the United States while I was in the Antitrust Division, I don't thinl: we found a single contract in which the inventor got his patent.

"Senator Kilgore. What would he get in lieu of it? ones."

"Judge Arnold. He would get $\$ 1$ from the big corporations and $\$ 25$ from the little

Hearings on S.702 Before a Subcommittee of the Senate Comnittee on Military Afjairs, 78th Cong., Ist Sess., pt. I, at 16 (1943).

OC The term "technical personnel" is only used in para. (b) (2) (i), and as noted above, the exclusionary provisions of that paragraph seldom come into operation. Thus, the tcrm is of minor significance. See note 57 supra.

67 Para. (b) (2).

08 When the contractor decides not to apply, notice is given either in the initial report (para. (c) (i), or by special notice not later than 8 months after first publication, public use or sale (para. (d) (i)). When the contractor discontinues prosecution of an application, notice is given not less than 60 days before the end of the response period (para. (d) (iv)), which apparently means the time allowed to respond to official action of the Patent Office. After review of the application and search for prior art references by the examining division, a decision, or first official action is made, usually requiring division or action on the merits. TouIMIN, HANDBOOK OF PATENTS 98 (2d ed. 1954). Unless otherwise indicated, the applicant has 6 months from the mailing date stanped on the official action, but a shorter period may be set by the examiner, also running from the date of the official action. If no response is made in the appreable period, the application becomes abandoned. $I d$. at 100 . Since different periods may apply, the contracting officer can not know the applicable period; hence the requirenient of notice not less than 60 days before the end of the period is necessary. It is obvious that if the contractor declines prosecution of the application less than 60 days from the end of the period, abandoninent will probably result.

${ }^{60}$ Para. (d) (ii) (B). If the contractor were adjudicated bankrupt a question arises whether a conveyance of title to the Government, following a decision not to patent, within 4 inonths of the petition would be a preferential transfer within the meaning of $\S 60$ of the Bankruptcy Act (64 Stat. 24 (1950), 11 U.S.C. $\$ 96$ (1958)). The Government is a creditor (1 CollIER, BANKRUPTCY II 1.11, at 75 (14th ed. 1956)), provided it has a provable claim under $\$ 63$ of the Bankruptcy Act (52 Stat. 873 (1938), as amended, 11 U.S.C. $\$ 103$ (1958)), whicb is probable since the area of provable claims is so broad. 1 CorrIER, Bankruptcy $\| 1.11$, at 73 (14th ed. 1956). Thus, the creditor relationship required by $\S 60$ of the Bankruptcy Act, which imposes the duty to return preferences, is met.

However, "prior to the 1938 Act it was held that the United States was not a 'person' under $\S 60$ so as to be liable to suit by the trustee for recovery of a voidable preference unless consent to suit was given." 3 Colimer, BANKRUPTCY \ $60.16 \mathrm{n} .3$ (14th ed. 1956). The word "person" is no longer used in this section, but it has been indicated the saine result would obtain since without consent the Government is immune. Ibid. However, if the Government voluntarily partici- 
in part at least, allows the Government to decide whether an invention is to be dedicated.$^{70}$ However, the armed services insist that assignment is necessary to protect against those who may later assert a patent. ${ }^{71}$ But if adequate protection against such belated assertions could be given by notice to the Defense Department at the time of the suit, thus enabling preparation of a defense, the contractor could dedicate, and huge files of reports would not be needed. ${ }^{72}$ Furthermore, many insist that it is unfair for the Government to assert patent rights against the public ${ }^{73}$ and therefore advocate the widest possible dedication. ${ }^{74}$

Among the rights acquired by the Government following assignment of title is the right to apply for and prosecute patent applications throughout the world ${ }^{75}$ subject to the contractor's prior right, under specified conditions. ${ }^{76}$ While no express provision regarding foreign rights is made where an application for a patent has been discontinued, the result is probably the same since foreign rights are preserved in the Government independently. ${ }^{77}$

Conveyance of title to the Government is made "subject further to the reservation of a non-exclusive and royalty-free hicense to the contractor," ${ }^{8}$ implying that the contractor's reserved license rights are neither irrevocable nor nontransferable..$^{70}$ The implication of nontransferability is weakened by the provision permitting "existing and future associated and affiliated companies, if any, within the

pates in the bankruptcy proceedings, it may be compelled to surrender the voidable preference. Ibid. There is a doubtful possibility the authorization and consent clause required under 32 C.F.R. \$ 9.102-2 (Supp. 1959) (see text at note 62 supra) would be deemed consent for this purpose.

70 In 1946, hearings were held on a bill requiring dedication to the public of all governmentowned patents (Hearings on H.R. 5842 and HR. 5940 Before the House Committee on Patents, 79th Cong., 2d Sess. (1946)), but it was never reported out of committee. 3 ATT'y GEN. REP. op. cit. supra note 2 , at 310-14.

71 Ibid.

72 See S. Rep. No. 1430, 85th Cong., 2d Sess. 7 (1958). S. 2277, 85th Cong., 1st Sess. (1957) embodies another method of providing necessary protection to the Government by allowing publication of the application on request of the application owner.

733 ATr'y Gen. Rep. 310-14. See also VaUgHAN, op. cit. supra note 50. "The Government has never instituted a suit charging an infringement of any of its patents, nor collected any royalties for the use of these patents by others" except in one instance involving compromise of a suit where the royalty has amounted to over one million dollars. S. REP. No. 1430, 85th Cong., 2d Sess. 7 (1958).

74 The vital importance of dissemination of scientific information, national defense considerations apart, is emphasized in testimony given in Hearings on S. 1297 and related bills Before the Subcommittee on War Mobilization of the Senate Committee on Military Affairs, 79th Cong., 1st Sess., at 546-47, 686-87, 703-05 (1945). 3 ATT'Y GEN. REP. 233. Absent security reasons, there seems little justification in depriving the contractor of the right of dedication.

75 This was not provided in the 1953 clause. The applicant for an American patent must sign the application and swear an oath he believes himself to be the original and first inventor. 35 U.S.C. $\$ 111$ (1952). Difficulties may exist if the Government applies in foreign countries where only the inventor may apply for and be issued the patent. Riesenfeld, Patent Protection and Atomic Energy Legislation, 46 CAIIF. L. REv. 40, 56 (1958).

In this situation, the Government may be unable to apply unless the country, such as Germany, recognizes the right of the assignee. See Riesenfeld, The New American Patent Act in the Light of Comparative Law, 102 U. PA. L. Rev. 723, 733 (1954).

76 See discussion of foreign rights, note $85 \mathrm{infra}$ and accompanying text.

77 Para. (e). See discussion of foreign rights, note 85 infra and accompanying text.

78 Para. (d) (ï) (B).

79 Cf. para. (b) (1) granting the Government an "irrevocable, non-exelusive, nontransferable, and royalty-free license." 
corporate structure of which the Contractor is a part" to share in the license, ${ }^{80}$ and by the provision that the license "shall be assignable to the successor of that part of the Contractor's business to which such Invention pertains." 81 While there are no similar provisions to show that omission of "irrevocable" is intended to make the hicense revocable, the reservation of a contractor's license was probably intended to be analogous to a shop right, and under the Dubilier doctrine ${ }^{82}$ this license is irrevocable.

Under an inspection provision, ${ }^{83}$ the Government may obtain from the contractor, on written or oral request, an irrevocable power of attorney to inspect and copy United States patent applications on imventions reasonably appearing patentable which are filed by or on behalf of the contractor. It is not clear whether any government employee, just one delegated by the contracting officer, or only that officer himself, may inspect the applications. While some delegation is undoubtedly desirable in the interests of efficiency, clearly there should be no "roving commission" enabling anyone in Government to examine the contractor's applications. ${ }^{84}$

\section{Foreign Rights}

In accord with the policy of the clause, the contractor has first chance to acquire the foreign patents to any invention, with a resulting license to the Government.8v However, if the contractor fails to avail himself of these rights within specified time himitations, the Government may under certain conditions require assignment of these rights.

After a corresponding application has been filed in the United States Patent Office, the contractor has 9 months in which to apply for foreign patents. ${ }^{83} \mathrm{But}$ "corresponding United States application"87 is nowhere defined and it may therefore prove difficult to determine. To require identical applications may be impossible where the foreigi patent system has different techniques of describing the invention, contrasting with the American "objectives" and "claims" system. ${ }^{88}$ For example, an improvement-patent application filed in the United States may be on the same invention for which the inventor could get a generic patent abroad. Although the clause gives no indication of the degree of correspondence required, where a foreign patent application claims less than the domestic application so that a significant part of the invention is not exploited, the Government should be allowed to demand title to the foreign rights in the interest of full exploitation of the invention.

80 Para. (d) (ii) (B). There seems to be no justification to limit the contractor's affiliates to corporations. If this is true, probably a partnership affiliate of a one-man-firm contractor should share in the license.

81 Ibid.

82 United States v. Dubilier Condenser Corp., 289 U.S. 178 (1933); 3 ATr'y GEN. REP. 140.

83 Para. (c) (iii). Inspection would tend to protect the Government from consequences of the contractor's failure to give notice of abandonment of the application. See note 68 supra.

84 "Pending patent applications are preserved in secrecy." 37 C.F.R. $\$ 1.14$ (Supp. 1959).

85 Para. (e). This paragraph was introduced to the clause in 1956.

80 Para. (e) (i). This provision reduces by 3 nuonths the contractor's right under the Paris Convention to preserve lis priority by filing an application in a signatory nation within 12 months from the date an application is filed in the United States Patent Office. See International Convention for the Protection of Industrial Property, March 20, 1883, revised June 2, 1934, art. 4, para. C, 53 Stat. 1773, T.S. No. 941 (effective Aug. 1, 1938). According to the revisers' notes, 35 U.S.C. $\$ 119$ (1952) accords with the requirements of this convention.

87 Para. (e) (i).

88 For differing foreign practices see Riesenfeld, The New American Patent Act in the Light of Comparative Law, 102 U. PA. L. Rev. 723 (1954). 
When foreign filing has been prohibited by security rules, the clause gives the contractor 6 months after lifting of the "security blanket" in which to apply for foreign patents. The security rules stem from the Patent Act of $1952^{89}$ which provides for secrecy and withholding of a paent grant when the Department of Defense (or other agency) having a property interest in the invention determines that disclosure might be detrimental to the national interest. Under the patent sections of the Armed Services Procurement Regulations, ${ }^{90}$ the contractor gives notice of patent applications to the contracting officer for determination whether the application should be put in "cold storage" in accordance with the Patent Act. ${ }^{11}$ Where these security rules apply, the contractor is prevented from applying for foreign patents on subject inventions without the approval of the contracting officer. ${ }^{02}$

Although any of the time limitations may be extended by the contracting officer, upon expiration title to the foreign rights must be assigned to the Governinent upon request. In general, the assignment is subject to the same rules as conveyance of title discussed above. ${ }^{93}$ However, the instructions for the use of the clause ${ }^{94}$ provide that a conveyance of foreign rights is not necessary, unless the Government intends to apply for foreign patents. Furthermore, there is no requirement that the contractor execute foreign patent applications; only conveyance of rights is required. So if the Governinent las no status to apply for a foreign patent, ${ }^{95}$ it can gain none, unless the contractor voluntarily applies for the benefit of the Government.

While assignability of other rights under the clause is elsewhere limited to corporate affiliates of the contractor, ${ }^{96}$ or a successor to that part of the contractor's business to which the invention pertains, ${ }^{97}$ it is provided that the contractor's foreign rights run to other parties "deriving rights from him,"98 implying no such limitations of assignees. If this is so, a somewhat strange result obtains when a successor to part of the contractor's business other than that to which the invention pertains, is assigned foreign rights by the contractor. If the time limits given in paragraph (e) expire and the Government demands the foreign rights, ${ }^{99} \mathrm{a}$ re-

8035 U.S.C. $\$ \S 1-293$ (1952).

0032 C.F.R. $\$ 9.106$ (Supp. 1959) requires insertion of a security clause in every classified contract and every unclassified contract likely to cover classified subject inatter.

01 If the application discloses subject matter classified Confidential, the contractor merely sends a copy to the contracting officer at or before the time of filing. Id. at para. (b). If, however, the subject matter is classified Secret or higher, the application itself is subinitted, together with a citation of the provision that if no instructions are given by the contracting officer in thirty days of transmission, the application may be filed in the Patent Office. Id. at para. (a).

0235 U.S.C. $\$ 184$ (1952). Where a classified contract is to be performed outside the United States, its territories or possessions, or Puerto Rico, the contractor is barred from filing any patent application disclosing classified subject inatter without the contracting officer's approval. 32 C.F.R. § 9.106-1 (Supp. 1959).

93 See text at note 68 supra.

94 32 C.F.R. \& 9.107-2(b) (Supp. 1959).

95 See discussion at note 75 supra.

06 Para. (d) (ii) (B).

87 Paras. (d) (ii) (B), (e) (iii).

98 Apparently sublicenses to foreigners are not barred. Without government controls this may be poor policy, from a national defense standpoint, but seems appropriate from a dissemination of technical information view. See note 74 supra.

89 Para. (e) (iii). 
sulting license ${ }^{100}$ would inure not to the assignee, but to another party: the contractor or the successor to that part of the business to which the invention pertains. This result may be justified on the ground that the assignee had a chance to protect his foreign rights, but having failed to do so, is no longer entitled to the license.

\section{Subcontracts}

The subcontracts paragraphs of the clause ${ }^{101}$ seek to include patent clauses in subcontracts which will inure to the benefit of the Government by providing that "the Contractor shall exert all reasonable effort in negotiating for the inclusion of the Patent Rights clause" ${ }^{102}$ in all subcontracts. ${ }^{103}$ The negotiation concept is unique; the prime contractor must accept the entire clause or lose the contract while the subcontractor may be able to obtain a less stringent clause. ${ }^{104}$ Obviously, such flexibility is undesirable to the extent that it defeats uniform application of the patent clause, but it must be recognized that the subcontractor may be far less dependent upon Defense Department business than prime contractors. Negotiation enables the Government to obtain some protection without jeopardizing the performance of the contracts. ${ }^{105}$

If any delay in performance of the prime contract may result from subcontract patent rights negotiations, no patent rights need be granted by the subcontractor. ${ }^{106}$ The contracting officer may, on request of the contractor, ${ }^{107}$ waive or modify the requirement for a subcontract patent-rights clause when that requirement prevents the contractor, after "all reasonable effort," from signing a subcontract. If in 35 days after its receipt, the contracting officer has not denied the

100 Conveyance of foreign rights is subject to a bcense in the contractor, with a right to sublicense. The discussion of the nature of the bicense in text to note 96 supra seems equally applicable here. Under the technical data provision, discussed in text to note 162 infra, the Government may have the right, in the interest of the United States, to allow foreign governments the use of technical data dehvered by the contractor in accordance with the contract. 32 C.F.R. $\$ \S 9.203,206$ (Supp. 1959). See, e.g., Interchange of Patent Rights and Technical Information for Defense Purposes, Agreement with Australia, Jan. 24, 1958 [1958] 9 U.S.T. \& O.I.A. 5, T.I.A.S. No. 3974.

101 Paras. (g)-(i). If there were several contracts and amendments covering a research and development project, a question could arise which contract applies to the subcontractor. See para. (a) (iii). However, as most research and development contracts carry the same clause, the problem seldom would be faced.

The subcontracts paragraphs are carried over, with insignificant changes, from the 1953 clause. 32 C.F.R. \$\$ 9.107-1(f)-(h) (1954). The 1945 War Department clause (2 ATT'Y GEN. REP. 487-90) and the 1941 Navy Department clause used throughout World War II (id. at 299) are silent on the matter of suhcontracts.

102 Para. (g). If the contract relates to atomic energy, the contractor is required to insert the atomic energy patent rights clause in all subcontracts, unless the Atomic Energy Commission authorizes a deviation. 32 C.F.R. \$ 9.107-4 (Supp. 1959).

103 The suhcontract must involve $\$ 3000$ or more and must have research and development as one purpose. See discussion of "purposes" in text to note 21 supra. Whether a patent rights clause could he included in a subcontract not meeting the two requirements is uncertain.

104 Some government control over subcontract negotiations is afforded hy the provision: "In the event of refusal by a suhcontractor to accept such a patent rights clause, the Contractor shall not proceed with the subcontract without written authorization of the Contracting Officer," and upon obtaining such authorization, shall cooperate with the Government in the negotiation with such subcontractor of an acceptable patent rights clause. Para. (g).

105 The Defense Department also asserts that stringent patent clauses make it difficult and costly to contract with competent firms. See Kreeger, The Control of Palent Rights Resulting from Federal Research, 12 LAW \& CONTENop. ProB. 714 (1947).

108 Para. (i).

${ }_{107}$ The request unust cite the waiver or termination provision. 
request for waiver (or modification) im writing, the requirement is automatically waived. ${ }^{108}$ On the other hand, written denial within 35 days automatically terminates the prime contract "and the rights and obligations of the parties shall be governed by the provisions of the clause of this contract providing for termination for the convenience of the Government." 100 Obviously, this termination provision coerces the contracting officer to grant the request.

The delay paragraph ${ }^{110}$ provides an escape for the contractor from the requirements of the negotiation paragraph. If subcontract patent-rights negotiations cause delay in performance of the prime contract, extension of delivery dates for the duration of the delay and increased prime contract price may be authorized by the contracting officer. To qualify for this authorization, the contractor must establish that: (1) the delay resulted from the requirements of the negotiation paragraph; (2) the potential subcontractor was "qualified;"111 (3) the subcontract was for an item or service required under the prime contract; and (4) the contractor itself did not have the facilities or qualified personnel to furnish the item or service. The contracting officer may grant further relief by an additional extension of delivery dates and may "increase the contract prices based upon additional costs incurred by such delay"112 as is proper in the circumstances. If this is done, the prime contract is automatically modified accordingly.

The negotiation paragraph has a proviso apparently intended to standardize the patent rights among the three parties:

The Contractor shall in any event require the subcontractor to grant to the Government patent rights under Subject Inventions of no less scope and on no less favorable terms than those which the Contractor has under such subcontracts, except that in no event shall the subcontractor be required to grant to the Government patent rights in excess of those herein agreed to be granted to the Government by the Contractor. ${ }^{113}$

Literally read, the proviso would preclude the Government from getting any rights where the prime contract had no patent clause, although as a practical matter the contractor would probably get at least a license and perhaps even title from the subcontractor. ${ }^{114}$

The contractor is required to make three separate reports to the contracting officer relating to subcontracts: (1) notification of the existence of any subcontract containing a patent rights clause; (2) notification of the terms of the clause; and (3) notification of completion of the subcontract. ${ }^{115}$ These reports are to be subnitted at the "earliest practicable date" and non-compliance is penalized.116

The reporting paragraph further provides that the Government is a third party

108 The automatic waiver provision does not apply to patent rights provisions "relating to the production or utilization of special nuclear material or atomic energy ...." Para. (g).

100 Para. (i). Termination for the benefit of the Government is far more advantageous to the contractor than other types of termination. See 32 C.F.R. $\$ \S 8.000-8.807$ (Supp. 1959).

110 Para. (i).

121 The word "qualified" is without definition. The definition of the analogous phrase "responsible prospective contractor" in 32 C.F.R. $\$ 1.902$, added by 24 Fed. Reg. 6563 (1959), may be helpful, although the section does not directly apply to subcontractors. See also 32 C.F.R. \& 1.906, added by 24 Fed. Reg. 6564 (1959).

112 Para. (i).

113 Para. (g).

114 3 ATT'y GEN. REP. 73 indicates the contractor probably gets broader rights than are acquired by the Government, and a recent addition to the clause specifically authorizes negotiation for broader rights. Para. $(\mathrm{g})$.

115 Para. (b).

116 Para. (f) (iii). 
beneficiary of the subcontract patent-rights clause. ${ }^{117}$ But of more practical use to the Government is the assignment to it of the contractor's rights "to enforce the subcontractor's obligations for the benefit of the Government with respect to Sub. ject Inventions," 118 although the contractor is released from any duty to enforce the subcontract's patent-rights clause. ${ }^{119}$

\section{E. Enforcement}

Three different reports ${ }^{120}$ as well as certain additional information are required of the contractor. All reports and other information are required only for "Subject Inventions which reasonably appear to be patentable,"121 but the regulations are not clear to whom the invention is reasonably to appear to be patentable, or at what point in time the determination is made. ${ }^{122}$

Three reports-initial reports, ${ }^{123}$ interim reports, ${ }^{124}$ and a final report ${ }^{126}$-are required in addition to the three reports on subcontracts. ${ }^{128}$ An mitial report is to be inade on each reportable invention "promptly after conception or first actual reduction to practice"127 or whenever a subject invention reasonably appearing patentable is first disclosed on an interim ${ }^{128}$ or final ${ }^{120}$ report, or is otherwise known to be unreported.

Interim reports must list all reportable inventions "conceived or first actually reduced to practice more than three months prior to the date of the report"130 and

117 In a third party beneficiary contract "the promisor engages to the promisee to render some performance to a third person." 2 WIIIISTON, CoNTRACTs $\$ 347$ (rev. ed. 1936). To fit this definition the promisor in the contract containing the patent rights clause ought to be the sub. contractor who is not a party to the contract. However, this contract is between the beneficiary (Government) and the promisee (contractor). Hence, no third party beneficiary situation exists, apart from a clause in the subcontract. Except on the basis of experience, which is not available, whether a subcontract will contain any patent rights provision is not predictable. See text to note 109 supra.

118 Para. (h).

110 Ibid. The policy behind this provision is difficult to see, even though the Government has been assigned the enforcement rights. Perhaps the contractor is considered to have done his part by getting a patent rights clause in the subcontract.

120 Para. (c).

121 Reporting solely on inventions reasonably appearing patentable has been government practice for some time. 32 C.F.R. $\$ 9.107-1$ (c) (i) (1954). A similar provision was in the War Department's patent rights clause adopted in April 1945. 2 ATT'Y GEN. REP. 487. The Navy Department first required contractors to report their inventions in 1942. Id. at 305.

122 Where, in accordance with the contract, the contracting officer makes determinations of fact with right of appeal to the head of the Department, the decision of the latter is final. United States v. Wunderlich, 342 U.S. 98 (1951). A "finality" clause similar to the one considered in that case is inserted in cost reimbursement supply contracts. 32 C.F.R. $\$ 7.203-12$ (Supp. 1959). However, this section does not apply to research and development contracts. 32 C.F.R. $\$ 7.202$ (Supp. 1959).

123 Para. (c) (i). The term "initial report" is used instead of written disclosures as in the clause.

124 Para. (c) (ii) (added in 1956).

125 Para. (c) (iii) (added in 1956).

126 See text to note 115 supra.

127 Para. (c) (i). The 1953 clause required the initial report 6 months after first publication, public use or sale. 32 C.F.R. $\$ 9.107-1$ (c) (i) (1954).

128 This is because an invention disclosed first on an interirn report, with no supporting initial report, is a ground for penalty under paragraph (f) (ii).

129 Conception in the interval between the last interim report and the final report is one instance where an invention is properly first disclosed in the final report.

130 Para. (c) (ii). 
are required annually, starting with the date of the contract. Inventions listed on prior interim reports need not be listed. If no reportable inventions were made, a statement to that effect is required.

The final report catches up with all reportable inventions, whether or not actually reduced to practice, including all inventions listed on the interim reports. If an invention is never actually reduced to practice during the life of the contract, it need not be disclosed or listed on an interim report but inust be included in the final report. The final report is due when 80 percent of the contract amount, as amended, has been paid.131

In addition to disclosure of the invention, the initial report must include a "written statement specifying whether or not a United States patent application claiming the Invention has been or will be filed by or on behalf of the Contractor."132 When the contractor states that he will file a patent application, the clause imposes a duty of so filing "in due form and time;" if he then changes his mind, he must notify the contracting officer at the earliest practicable date or not later than 8 months after first publication, public use, or sale. ${ }^{133}$ This latter date introduces a new measuring period into the clause. It is theoretically possible for the contractor to delay first publication, public use, or sale until after final settlement of the contract, thereby increasing enforcement difficulties of the Government, since penalties under paragraph (f) would be unavailable. However, the inspection provision of the assignment section, ${ }^{134}$ and the doctrine of due diligence in prosecuting patent applications ${ }^{135}$ would tend to discourage such practice.

If the contractor decides not to file an application or discontinues the prosecution of one already filed, he inust report in writing at the earliest practicable date: (1) the name and date of any publication disclosing the invention when made by or known to the contractor, or (2) the name and date of any publication in which the contractor contemplates disclosure. ${ }^{136}$ If he neither knows nor publishes himself, no notification is required. These requirements assist the Government in protecting its rights by avoiding "public use," "publication," and "sale"- the noveltydestroying conditions listed in the 1952 Patent Act. ${ }^{137}$

Enforcement of the reporting requirements of the clause is accomplished by requiring the withholding of the lesser of 10 percent of the amended contract amount or $\$ 5000$ from payments by the Government until the contractor furnishes the required reports. ${ }^{138}$ The penalty is to be applied when the contractor fails to furnish an interin report or an initial report on any reportable invention ${ }^{139}$ shown to be due by any interim report or "otherwise known to be due." 140 However, after payment of 80 percent of the contract amount, grounds for invoking a penalty change, and the appropriate amount is withheld until the contractor furnishes: (1)

131 Para. (f).

132 Para. (c) (i).

133 Para. (d) (i). If the contractor elects not to continue after filing, notification is required not less than 60 days before the end of the response period. Para. (d) (iv); see note 68 supra. 134 Para. (d) (iii).

135 Marconi Wireless Tel. Co. v. United States, 320 U.S. 1 (1943).

136 Para. (d) (ii) (A). Reporting of publications was not required under the 1953 clause. 13735 U.S.C. $\$ \S 102$ (a), (b) (1952).

138 Para. (f).

139 The penalty section refers to "Subject Inventions required by (c)," i,e., those reasonably appearing patentable. Most probably the contracting officer could not demand reports on all subject inventions, on the ground they are "otherwise known to be unreported."

140 Para. (f). 
the final report, ${ }^{141}(2)$ all delinquent initial reports, and (3) all subcontract patent reports. ${ }^{142}$ Although there is no forfeiture provision, final settlement of the contract apparently niay be withheld until all delinquent reports are submitted. ${ }^{143}$

The penalties section provides that the maximum amount to be witheld is the lesser of 10 percent or $\$ 5000,144$ thus limiting the amount of penalties to be in1posed at one time regardless of the number of breaches. ${ }^{14 \bar{s}}$ Curiously, however, it is provided that "no amount shall be withheld under this paragraph ( $f$ ) when the amount specified by this paragraph (f) is being withheld under other provisions of this contract." ${ }^{146}$ Obviously, to allow imposition of a penalty under another provision of a contract to bar the sanctions of this paragraph defeats the enforcement of the reporting requirements. ${ }^{147}$

Finally, the contractor is informed that he is not required "to withhold any amounts from a subcontractor to enforce compliance with the patent provisions of [the] subcontract."148 Apparently, then, he could use the paragraph to impose like penalties for breach of patent provisions of a subcontract if he chose to do so. This would seem desirable for reporting requirements of subcontractors ${ }^{140}$ would be practically unenforceable otherwise. However, this may place the contractor in a delicate and unfriendly position with the subcontractor. Therefore, both from the view of getting reports as well as encouraging teamwork, a mandatory subcontract penalty seems necessary.

\section{II}

\section{RECENT CHANGES}

Before January 1955 there was provision for Government acquisition of licenses or other rights to background patents- "covering inventions antedating the contract and incorporated in the devices delivered under the contract"150_-in

141 The final report is required by paragraph (c)(iii). Since both interim and final reports are new to the 1956 clause, the 1953 penalty section did not: apply to thein.

142 Paragraph (h) requires subcontracl. patent rights reports but only when the subcontract contains a patents clause.

143 Apparently interim reports are not necessary after payment of $80 \%$ of the contract, since the penalty provision then relevant does not require them. Furthermore, that penalty is automatically imposed until the final report is submitted and two sinultaneous penalties are prohibited.

144 The alternate limit of $10 \%$ of the contract price does not include amendments to the contract, although they are mentioned twice by paragraph (f) in other situations. This omission is probably not inportant as most significant research and developinent contracts would be over $\$ 50,000$, so the $\$ 5,000$ penalty would apply. However, since anendments to one small contract may enlarge it considerably, this could be one minor factor in the contractor's decision whether a new contract or an amendment is desired to extend a basic contract.

145 However, two "half" penalties could conceivably comply with the restriction. The section is not clear whether a penalty once imposed in the maximum amount can be imposed at a later time for a subsequent breach. It is clear that if the first breach has not been cured, as discussed above, no further penalties may be imposed. However, if the second breach follows curing of the first, the question arises. Clearly, the purpose of the section would be defeated if no second penalty could be imposed.

146 Para. (f).

147 Since the penalties imposed by other provisions of the contract are generally equal in amount to the penalties section of the clause (see note 146 supra), apparently the contractor is only to be subjected to one penalty at a time.

148 Para. (f).

149 If a subcontract contains the patent rights clause, subcontractor reports are required by paragrapb (c).

1502 ATT'Y GEN. REP., op. cit. supra note 2, at 459. 
certain specified situations. ${ }^{151}$ The current regulation not only withdraws authority from the contracting officer to negotiate for background rights (other than where they are the main item to be procured) ${ }^{152}$ but implies that such practice is improper and undesirable. ${ }^{153} \mathrm{~A}$ similar fate befell the former provision allowing acquisition of title to foreground patents-"covering inventions conceived or first actually reduced to practice during performance of the contract and which relate to it"154_-by the Government. ${ }^{155}$

Another recent change provides that the Government may acquire licenses for patents conceived or first actually reduced to practice during supply contracts for specific product improvements. ${ }^{156}$ Although costs of general research, unless specifically provided for, are not allowed in supply and research cost-reimbursement contracts with commercial organizations, the Government may find it is supporting the contractor's independent research program. ${ }^{157}$ If the substantial part of that program is being supported by the Government, at the very least, license rights in patents developed by the contractor ought to go to the Government. Providing for licenses in product improvement contracts is one step in this direction. Other steps are being considered in the Department of Defense. ${ }^{158} \mathrm{~A}$ trend may be indicated by the recent amendment of this provision to include specific projects in the contractor's independent research program. ${ }^{159}$

The patent-rights clause of 1953 provided for disclosure by the Government for governmental purposes, including disclosure to foreign governments in the interests of the United States, ${ }^{100}$ of all technical data dehivered according to contract requirements. ${ }^{161}$ While no longer within the patent-rights clause under the current regulations, a similar provision is required to be inserted in all contracts for experimental, developmental, or research work. ${ }^{162}$ This is the cause of much worry to contractors who fear that their trade secrets will be divulged to competi-

15132 C.F.R. $\$ 9.107-3$ (1954).

15232 C.F.R. $\$ 9.107-1$ (b) (Supp. 1959).

153 "It is the policy of the Department of Defense, except as otherwise provided . . ., to pay a reasonable compensation for the use of a valid patent enforceable against the Government ...." Ibid.

A 1958 amendment made this provision inapplicable to contracts to be performed outside the United States, its possessions, territories, or Puerto Rico. Ibid.

1542 ATT'Y GEN. REP. 461.

15532 C.F.R. $\S 9.107-2$ (1954). This regulation gave five examples where government acquisition of foreground patent title is proper and desirable. The 1959 regulation does not accord this provision even a passing nod.

15632 C.F.R. \$ 9.107-6 (Supp. 1959). While the former regulation did not provide for patent rights in specific product improvement contracts, this was a feature of the pre-1942 Navy clause. See 2 ATt'x GeN. Rep. 299.

15732 C.F.R. $\S 15.205$ (j) (1954). However, 32 C.F.R. $\$ 15.502(\mathrm{~m})$ (Supp. 1959) provides

for "special consideration of such costs."

158 Hodges, Patent Policies and Procedures of the Department of the Army, 39 J. Pat. OFF. Soc'y 192, 206 (1957), refers to the problem.

15932 C.F.R. § 9.107-6 (Supp. 1959).

160 See note 100 supra.

10132 C.F.R. \$ 9.107-1(d) (1954). "Technical data" strictly defined means drawings, blueprints and reports. Hodges, supra note 158 , at 208 . The new regulation defines "data" as all "writings, sound recordings, pictorial reproductions, drawings or other graphical representations and works of any similar nature" furnished under the contract. 32 C.F.R. \$9.201(a) (Supp. 1959).

10232 C.F.R. $\S 9.202-2$ (b) (2) (Supp. 1959). 
tors, ${ }^{163}$ especially when the Government awards procurement contracts to firms other than the development contractor. ${ }^{104}$ Some protection is afforded by the new regulation which distinguishes between operational, descriptive and proprietary data. Operational and descriptive data are to be acquired by the Government in both supply and research and development contracts without limitation of use. Proprietary data is to be obtained under research and development contracts calling for models or practical processes without limitation of use when such data does not concern standard conmercial items or certain items developed at private expense. However, proprietary data is not to be requested in supply contracts, unless it is obtained to establish additional sources of supply, or for some emergency purpose, such as emergency government manufacture; in the latter case, the proprietary data is not to be otherwise released outside the Government. ${ }^{105}$ But it is obvious that the development contractor's competitive worries should not deter the supplying of technical data which the Government needs both to use the developed items and to keep abreast of current technology.

\section{CONCLUSION}

The necessity for soine type of patent provision regulating the rights of the parties under Government contracts is now generally recognized. But there is certainly no agreement whether title to the inventions should remain in the contractor with a license to the Governinent, as is presently the scheme, or vice versa.

The proponents of the present position rely mainly on the argument that to vest title in the Governinent would deter private industry from engaging in government contracts. ${ }^{166}$ Furthermore, not only would there be a lack of incentive to invent on the part of personnel, but, it is asserted, to vest title in the Government would increase the costs of research and development since the Government would be forced to coinpensate for loss of patent ownership. . $^{167}$

On the other hand, those in favor of government title to all patents resulting from government contracts point out the public is paying for the development of the inventions and thus should have the right to make the fullest utilization of the fruits of the contract. ${ }^{168}$ They discount any deterrent effect on industry enthusiasm to engage in government contracts; the license, the acquired "know-how" for competitive advantage, and the payment for the research itself are sufficient induce-

163 The problem is discussed at some length in Hodges, supre note 158, at 207-13. Trade secrets are also called "proprietary information" although the terms are not synonymous. See Forman, Proprietary Rights in Research and Development Contracting-A Case Study, 17 FED. B.J. 298 (1957).

164 The Armed Services Procurement Regulations provide the contracting officer should analyze carefully the advisability of awarding production contracts to development contractors, but caution against automatically selecting the development contractor, 32 C.F.R. $\$ 3.108$ (Supp. 1959).

165 See 32 C.F.R. $\$ \$ 9.200-9.206$ (Supp. 1959), as amended by 24 Fed. Reg. 3589 (1959). 32 C.F.R. $\$ 9.206$ (Supp. 1959) requires incorporation of an "unlimited use" clause in all contracts to be performed abroad.

160 This is considered the most serious objection by a government-title proponent. Kreeger, The Control of Patent Rights Resulting from Federal Research, 12 LAw \& ConTENr. PRos. 714 (1947). However, the author points out while there is very little evidence to support either argument on this ground, when the Army Quartermaster Corps sought assignment of title for 6 months during World War II, it was successful in about $50 \%$ of the cases.

1673 Att'y Gen. Rep. 250. See also Forman, Patents-Therf. OWNershir and AdManisTRATTON BY THE UNITED STATES GOVERNACENT (1957).

1681 ATI'Y GeN. REP. 4. 
ments to any contractor. ${ }^{169}$ Nor is there any increased discouragement to inventors since the title to inventions goes to someone else in either case. ${ }^{170}$

In addition, the government-title advocates urge that to allow contractors to retain title leads to "increased concentration of industrial research facilities in a few large industrial corporations" which means that the " overwhelming majority of American businesses' will lack 'adequate access to the benefits of scientific research and development." "171 However, the contrary program, they say, would promote a broad diversification of industrial and scientific resources with many units available in case of a national crisis. 172

That continued invention is essential to the development and safety of our nation is beyond question. ${ }^{173}$ Therefore, the resolution of the problem of patent regulation mainly depends on the effect on incentives to invent. Whether an award system may serve better than the present patent system, whether lack of patent protection will deter rather than promote industrial participation in government programs, are questions which depend upon the functioning of the patent system generally. The only answer possible at the present time was that given by Judge Learned Hand before a Senate committee in 1955. In response to a question whether the patent system was a good and useful thing in promoting arts and science, he stated:

Nobody knows and nobody can know until they examine how the system ... works in our present very complicated industrial society. . . . Each side is beating the air. They approach it with enormous passion but without enlightenment . . . Y You have no idea, you get no line whatever of information as to how the system itself is in fact influencing the production of inventions. .774

Thomas F. Olson*

100 Vaughan, The United States Patent System 314-16 (1956).

170 See note 65 supra.

171 Kreeger, supra note 166 , at 739.

172 Ibid. However, a currently lield doctrine of the Defense Department, the weapon system concept, works against this broad diversiflcation: an entire weapon, such as an airplane or missile, is turned over to one prime contractor who carries out research, development, evaluation and often production for the airframe, components, accessories, training aids and other closely connected items. The reason for this has been stated: "Not until ... the main burden of research, development and production slifted to the ... aviation industry did our military aviation begin to rise out of the technical doldrums." Aviation Week, Sept. 16, 1957, p.21. See also Aviation Week, Aug. 6, 1956, p. 86; Homann, Weapon System Concepts and Their Pattern in Produrement, 17 FED. B.J. 402 (1957); Livingston, Decision Making in Weapons Development, Harv. Bus. REv., Jan.-Feb. 1958, p. 127.

173 Hearings Before the Subcommittee on Patents, Trademarks, and Copyrights of the Senate Commitee on the Judiciary, 84th Cong., 1st Sess. 116 (1955). 174 Ibid.

* Member, Alameda County Bar. Mr. Olson, who graduated with the Class of 1958, wrote this Comment while he was a student at Boalt Hall. 